\title{
Variations in Arbuscular Mycorrhizal Colonization Associated with Root Diameter and Hypodermis Passages Cells across Temperate and Tropical Woody Species
}

\author{
Yan Wang ${ }^{1}$, Zhongyue $\mathrm{Li}^{1}$, Siyuan Wang ${ }^{2}$, Wenna Wang ${ }^{3}$, Na Wang ${ }^{4}$ and Jiacun Gu ${ }^{2, *(D)}$ \\ 1 Mountain Tai Forest Ecosystem Research Station of State Forestry Administration, College of Forestry, \\ Shandong Agricultural University, Tai'an 271018, China; wangyansilv@sdau.edu.cn (Y.W.); \\ lzy692@126.com (Z.L.) \\ 2 Key Laboratory of Sustainable Forest Ecosystem Management-Ministry of Education, School of Forestry, \\ Northeast Forestry University, Harbin 150040, China; wangsiyuan1007@126.com \\ 3 Institute of Tropical Agriculture and Forestry, Hainan University, Haikou 570100, China; \\ wennawang@hainanu.edu.cn \\ 4 Hunan Key Laboratory for Conservation and Utilization of Biological Resources in the Nanyue Mountainous \\ Region, College of Life Sciences and Environment, Hengyang Normal University, Hengyang 421008, China; \\ wangnsilv@163.com \\ * Correspondence: gjcnefu@nefu.edu.cn; Tel.: +86-451-82190614; Fax: +86-451-82191044
}

check for

updates

Citation: Wang, Y.; Li, Z.; Wang, S.; Wang, W.; Wang, N.; Gu, J. Variations in Arbuscular Mycorrhizal Colonization Associated with Root Diameter and Hypodermis Passages Cells across Temperate and Tropical Woody Species. Forests 2022, 13, 140 https://doi.org/10.3390/f13020140

Academic Editors: Antonino Di Iorio and Agostino Sorgonà

Received: 30 November 2021

Accepted: 17 January 2022

Published: 18 January 2022

Publisher's Note: MDPI stays neutral with regard to jurisdictional claims in published maps and institutional affiliations.

Copyright: (C) 2022 by the authors. Licensee MDPI, Basel, Switzerland. This article is an open access article distributed under the terms and conditions of the Creative Commons Attribution (CC BY) license (https:// creativecommons.org/licenses/by/ $4.0 /)$.

\begin{abstract}
Root hypodermis passage cells (PCs) lack suberin and lignin deposition, responsible for nutrient absorption and arbuscular mycorrhizal colonization, which are crucial for root resource acquisition. Nevertheless, their quantitative variability across diverse woody species and their relationships with root morphology and anatomy, as well as arbuscular mycorrhizal colonization, are still not well understood. Herein, the number and proportion of PCs in the root cross-section, root morphology, anatomy, and arbuscular mycorrhizal colonization rate were quantified across 10 temperate and 12 tropical woody species. The objectives of this study were to determine how PCs vary across contrasting environmental conditions and to explore their relationships with arbuscular mycorrhizal colonization rate and other root functional traits. The results showed that tropical species possessed 56\% more PCs than temperate species; by contrast, they had similar proportions of PCs. In both biomes, the number of PCs had a tightly positive correlation with arbuscular mycorrhizal colonization rate $\left(R^{2}=0.35-0.87\right)$, root diameter $\left(R^{2}=0.84-0.93\right)$, and cortex thickness $\left(R^{2}=0.87-0.89\right)$, but the proportion of PCs was mostly independent of root morphological and anatomical traits. Our results suggest that variation in passage cells could well explain the tight linkage between arbuscular mycorrhizal colonization and root diameter across species and biomes, which provides insight into the collaboration gradient between plant roots and mycorrhizal fungi that dominates the root economics space.
\end{abstract}

Keywords: absorptive roots; hypodermis passage cell; arbuscular mycorrhizal colonization; root anatomy; root diameter; biome

\section{Introduction}

In terrestrial ecosystems, most plant roots do not work alone; they build mutualistic associations with mycorrhizal fungi on their root system [1,2]. Fine roots colonized by mycorrhizal fungi are enhanced in their capacity for resource acquisition [3-5], affecting plant and ecosystem function [6,7]. Mycorrhizal colonization rate, evaluating the degree of colonization between mycorrhizal fungi and absorptive roots, is significantly positively related to root morphology and anatomy, e.g., root diameter and cortex thickness [8]. Species with contrast root traits show a complementary strategy for nutrient foraging of fine root and mycorrhizal fungi [3,4,8-11]. Nevertheless, the intrinsic mechanistic understanding of how mycorrhizal colonization rate and root traits could be related is not 
fully clear. Alternatively, one potential interpretation is hypodermis passage cells (PCs), which are crucial factors in setting up the symbiotic association.

In hypodermis, PCs are characterized by dense cytoplasm and display typical cytoplasmic structures, which are highly metabolically active cells [12]. Specifically, PCs could secrete strigolactone, which would attract and motivate extracellular arbuscular mycorrhizal (AM) fungi growth and branching, guiding hyphae nearly exclusive locate to PCs [13-16]. Additionally, PCs also lack suberin lamellae [17] and lignin deposits [18], which enable AM fungi to penetrate into PCs easily [17]. Consequently, AM fungi would colonize fine roots exclusively through PCs, as conceptualized in Figure 1. Previous studies also proved that increased number [19] or proportion of PCs [20,21] could induce higher AM colonization rate, respectively. Given the close linkage between AM colonization rate and root diameter and cortex thickness, it is also reasonable to assume the number or proportion of PCs would be closely related to root diameter and cortex. For example, thick root tips possessed a greater number of PCs than thin ones in potted seedlings of various citrus rootstocks ( $r=0.43, p=0.0056)$ [22]. However, less detailed information is revealed about the direction and magnitude of potential linkages of the quantitative characteristic of PCs, in terms of their number and proportion, with root diameter and cortex, as well as the coordination among these root traits (Figure 1).

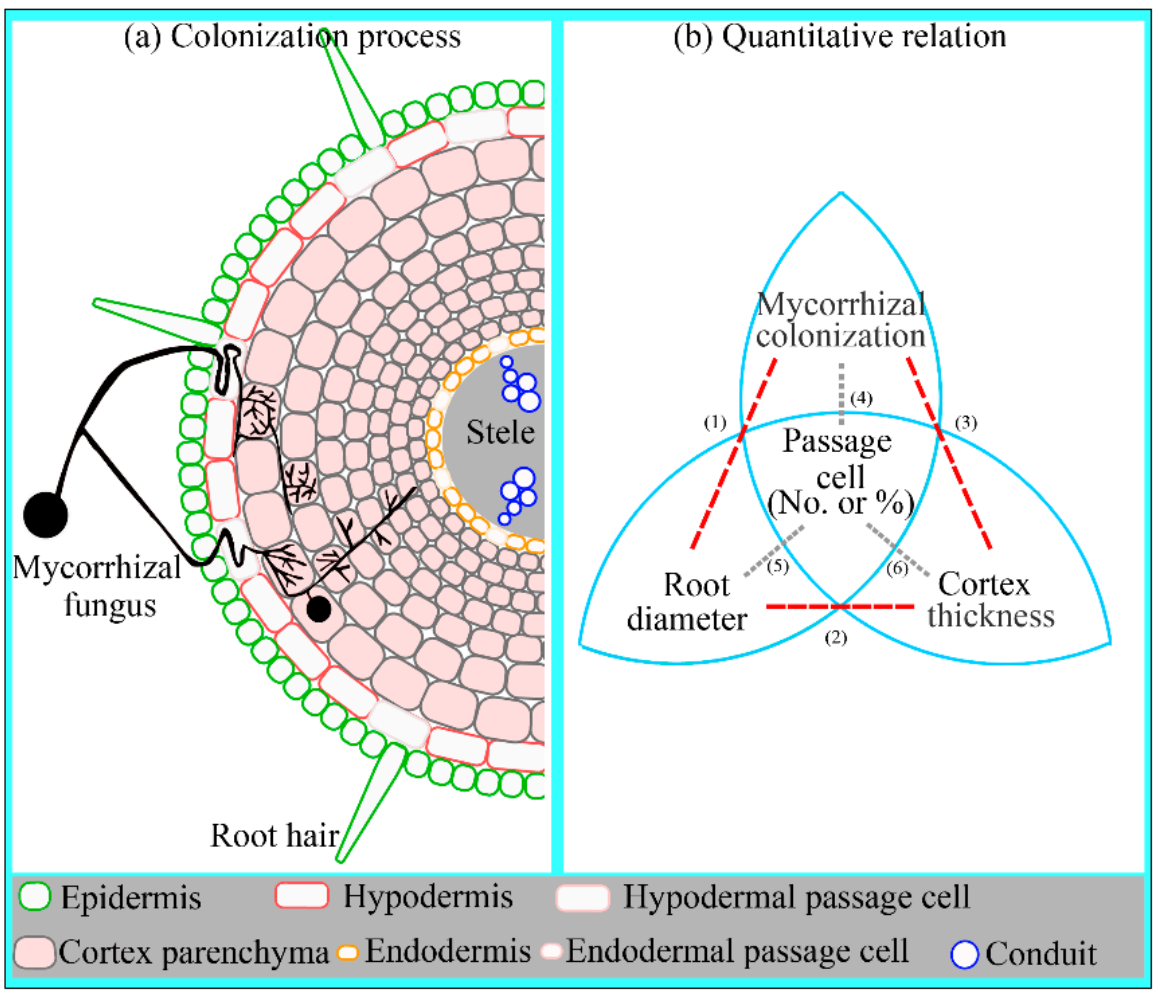

Figure 1. Arbuscular mycorrhizal colonization process and quantitative relation: (a) arbuscular mycorrhizal fungi penetrate into fine root through passage cells (PCs), then proliferate within cortical cells, typical hyphal structures including the vesicles, arbuscular and hyphal coils; (b) correlation of trait pair in mycorrhizae, including mycorrhizal colonization (MC), root diameter (RD), cortical thickness (CT), and PC. The positive relationships (indicated by red dotted lines) of trait pair within (1) MC-RD has been proved in Ma et al. [8]; (2) RD-CT in Bergmann et al. [11] and Guo et al. [23]; (3) MC-CT in Guo et al. [23], respectively. However, the positive relationship (indicated by grey dotted lines) of trait pair within (4) PC-MC has been confirmed in Xu et al. [21] (both the number and proportion of PCs in root length); (5) PC-RD in Eissenstat and Achor [22] (the number of PC), but scarcely in (6) PC-CT. 
Recently, the functional variation in fine root traits and their associations with symbiont organisms is an emerging issue to better understand the diverse root resource acquisition strategies [24-26], and multidimensional root traits variations have been integrated into collaboration and conservation gradients [11]. Based on the root size and the degree of dependence on mycorrhizal fungi, the gradient of plant collaboration strategies ranges from "do it yourself" to "outsourcing". These outsourcing strategies have consequences for root traits, manifested by wide cortex and thick diameter, providing the intraradical habitat for their mycorrhizal fungal partner [11]. As the entrance of fungi, hypodermis PCs might function as the "valve", coupling fungi and cortical cells and facilitating the symbiont establishment. Together with the results of PCs and AM colonization rates reported in Xu et al. [21], more details about PCs' variations, and their correlations with other root traits (e.g., root diameter and cortex thickness) would shed light on the coordination between root morphology, anatomy, and AM fungi, and deepen our understanding in the conceptual framework of root economics space [11].

In the current study, we selected 12 and 10 species in tropical and temperate forests in China, respectively (Table 1). These two sampled forests differed largely in environmental conditions such as precipitation and nutrient availability (Table S1). The sampled species are dominant species in each site, exhibiting a wide range in root size, as shown by our previous study [27]; all these species are colonized by AM fungi. We recorded the number of hypodermis PCs in the maturation zone of root-tip cross-sections, calculated their proportions for each species, and measured root AM colonization rates, morphology, and anatomy, after which we tested their potential interrelationships. Specifically, based on the knowledge gaps between PCs and other root traits in Figure 1, we sought to test the hypothesis that both the number and proportion of PCs were positively related to AM colonization rate, root diameter, and cortex thickness in temperate and tropical forests, respectively. We expect the linkages between PCs and root traits to be general across different biomes with distinct environment types and plant species. Addressing this issue will advance our understanding of the intrinsic mechanism for the root traits' tight associations.

Table 1. Taxonomic list, life form, dominant mycorrhizal (MYC) type, vegetation type, and sampling forests of the 22 species in this study.

\begin{tabular}{|c|c|c|c|c|c|c|}
\hline Family & Species & $\begin{array}{c}\text { Species } \\
\text { Abbreviation }\end{array}$ & Life Form & MYC & $\begin{array}{l}\text { Vegetation } \\
\text { Type }\end{array}$ & Sampling Forest \\
\hline \multirow[t]{2}{*}{ Adoxaceae } & Viburnum opulus L. & Viop & $\mathrm{D}$ & $\mathrm{AM}$ & S & Temperate \\
\hline & Viburnum odoratissimum Ker.-Gawl. & Viod & $\mathrm{D}$ & AM & $\mathrm{N}$ & Tropical \\
\hline Altingiaceae & Liquidambar formosana Hance & Lifo & $\mathrm{D}$ & $\mathrm{AM}$ & $\mathrm{N}$ & Tropical \\
\hline Caprifoliaceae & Lonicera maackii (Rupr.) Maxim. & Loma & $\mathrm{D}$ & AM & $\mathrm{S}$ & Temperate \\
\hline Celastraceae & Euonymus alatus (Thunb.) Sieb. & Eual & $\mathrm{D}$ & AM & $S$ & Temperate \\
\hline Cornaceae & Alangium chinense (Lour.) Harms & Alch & $\mathrm{D}$ & AM & $\mathrm{N}$ & Tropical \\
\hline Eucommiaceae & Eucommia ulmoides Oliver & Euul & $\mathrm{D}$ & AM & $\mathrm{N}$ & Tropical \\
\hline Hypericaceae & Cratoxylum cochinchinense (Lour.) Bl. & Crco & $\mathrm{D}$ & $\mathrm{AM}$ & $\mathrm{N}$ & Tropical \\
\hline Lauraceae & Alseodaphne hainanensis Merr. & Alha & $\mathrm{E}$ & AM & $\mathrm{N}$ & Tropical \\
\hline Magnoliaceae & Manglietia hainanosis Dandy & Maha & $\mathrm{D}$ & AM & $\mathrm{N}$ & Tropical \\
\hline Malvaceae & Sterculia lanceolata Cav. & Stla & $\mathrm{D}$ & $\mathrm{AM}$ & $\mathrm{N}$ & Tropical \\
\hline \multirow[t]{2}{*}{ Oleaceae } & Fraxinus mandshurica Rupr. & Frma & $\mathrm{D}$ & AM & $\mathrm{P}$ & Temperate \\
\hline & Syringa reticulate Blume & Syre & $\mathrm{D}$ & AM & $S$ & Temperate \\
\hline Phyllanthaceae & Aporosa dioica (Roxb.) Müll.Arg. & Apdi & $\mathrm{E}$ & AM & $\mathrm{N}$ & Tropical \\
\hline \multirow[t]{3}{*}{ Rutaceae } & Phellodendron amurense Rupr. & Pham & $\mathrm{D}$ & AM & $\mathrm{P}$ & Temperate \\
\hline & Acronychia pedunculata (L.) Miq. & Acpe & $\mathrm{E}$ & AM & $\mathrm{N}$ & Tropical \\
\hline & Fortunella margrita Lour. & Foma & $\mathrm{D}$ & AM & $\mathrm{N}$ & Tropical \\
\hline \multirow[t]{3}{*}{ Sapindaceae } & Acer mandshuricum Maxim. & Acma & $\mathrm{D}$ & AM & $\mathrm{S}$ & Temperate \\
\hline & Acer ginnala Maxim. & Acgi & $\mathrm{D}$ & AM & $S$ & Temperate \\
\hline & Acer mono Maxim. & Acmo & $\mathrm{D}$ & AM & $S$ & Temperate \\
\hline Schisandraceae & Schisandra chinensis (Turcz.) Baill. & Scch & $\mathrm{D}$ & AM & $S$ & Temperate \\
\hline Thymelaeaceae & Aquilaria sinensis (Lour.) Spreng. & Aqsi & $\mathrm{E}$ & AM & $\mathrm{N}$ & Tropical \\
\hline
\end{tabular}

Note: Life form is classified as deciduous (D) and evergreen (E). All mycorrhizal types are arbuscular mycorrhizas Additionally, vegetation type is classified as secondary forest $(S)$, natural forest $(N)$, and plantation $(P)$. 


\section{Materials and Methods}

\subsection{Study Site}

Two study sites were selected. One was located in a tropical forest in the Jianfengling National Natural Reserve $\left(18^{\circ} 23^{\prime}-18^{\circ} 50^{\prime}\right.$ N, $108^{\circ} 36^{\prime}-109^{\circ} 05^{\prime}$ E) in Hainan of southern China. The other was located in a temperate forest at the Maoershan Research Station $\left(45^{\circ} 21^{\prime}-45^{\circ} 25^{\prime} \mathrm{N}, 127^{\circ} 30^{\prime}-127^{\circ} 34^{\prime} \mathrm{E}\right)$ of the Northeast Forestry University in Heilongjiang of northeastern China. The tropical sampling site has a tropical climate with mean January, July, and annual temperatures of $19.4,27.3$, and $24.5^{\circ} \mathrm{C}$, respectively. The mean annual precipitation is $2266 \mathrm{~mm}$, of which $\sim 80 \%$ occurs between May and October. Soils are Laterite soil [28] with high nutrient leaching. Under such climate conditions, tropical seasonal rainforest dominates this mountainous area. In comparison, the temperate sampling site has a continental temperate monsoon climate with mean January, July, and annual temperatures of $-19.6,20.9$, and $2.8{ }^{\circ} \mathrm{C}$, respectively. The mean annual precipitation is $723 \mathrm{~mm}$, with $\sim 65 \%$ falling from June to August. Soils are Haplic Luvisols [28], well drained with high organic matter. This site is dominated by the secondary forest regenerated after the old-growth of mixed Korean pine and hardwood forest was harvested over 70 years ago. More details about the geographical, climatic, and edaphic information of the two sites are shown in Table S1.

\subsection{Species Selection and Root Sampling}

We sampled a total of 22 woody species, belonging to 16 families and 19 genera, 12 at the tropical site and 10 at the temperate site, respectively (Table 1). Based on a previous publication, Gu et al. [27] reported the variations of root anatomical variation across tropical and temperate species. Recently, our research interests focused on the variation in passage cells between two different biomes. More root samples of temperate species were collected to make sure the sample size was adequate for analysis. Therefore, roots samplings were conducted in August 2009 and August 2015 in tropical and temperate forests, respectively. All selected species are colonized by AM fungi and are common in both biomes. Herein, ectomycorrhizal species were excluded, since the external hyphal mantle and internal Hartig net limited microscopic observation for distinguishing passage and non-passage cells (Figure S1).

In each site, three target trees were selected for each species, with ages ranging from 30 to 50 years and diameters at breast height (DBH) from 15 to $20 \mathrm{~cm}$. Following the same procedure as in Guo et al. [23], three root branches (up to the fifth order) at the top $10 \mathrm{~cm}$ soil layer were sampled from each target tree. Root branches were traced to the tree stem and cut from the main lateral woody roots, which enabled us to identify and sort the roots of the target species. Roots from other tree species or herbaceous were removed based on root form, color, and elasticity $[23,27]$. Root samples were gently washed in deionized water firstly and then immediately fixed in a formalin-aceto-alcohol (FAA) solution $(90 \mathrm{~mL}$ of $50 \%$ ethanol, $5 \mathrm{~mL}$ of $100 \%$ glacial acetic acid, and $5 \mathrm{~mL}$ of $37 \%$ methanol) [23]. Samples were placed in a cooler, then stored at $4{ }^{\circ} \mathrm{C}$ until subsequent anatomical analyses.

\subsection{Root Anatomy and Morphology}

In the laboratory, each root branch was cleaned again to remove residual soil particles with a small brush. About 5-10 root tips from each tree were randomly dissected with forceps; a total of 20-30 root tips were sampled for each species. Only fibrous root tips (excluding pioneer root tips) were used to determine the characteristics of PCs, AM colonization, morphology, and anatomy because they are primarily responsible for water and nutrient uptake [23,29], and are more sensitive to environmental conditions [8]. In our preliminary experiment, the Berberine-Aniline blue procedure was conducted to distinguish the endodermal and hypodermis PCs [30]; however, it could not be applied in the formal experiment because of well hypodermis auto-fluorescence in the examined species. Thus, root maturation zone (possessing root hair and well-developed xylem, Figure 2) without 
staining were manually prepared using an SZX7 dissecting microscope (Olympus, Tokyo, Japan), as previously described [31,32].

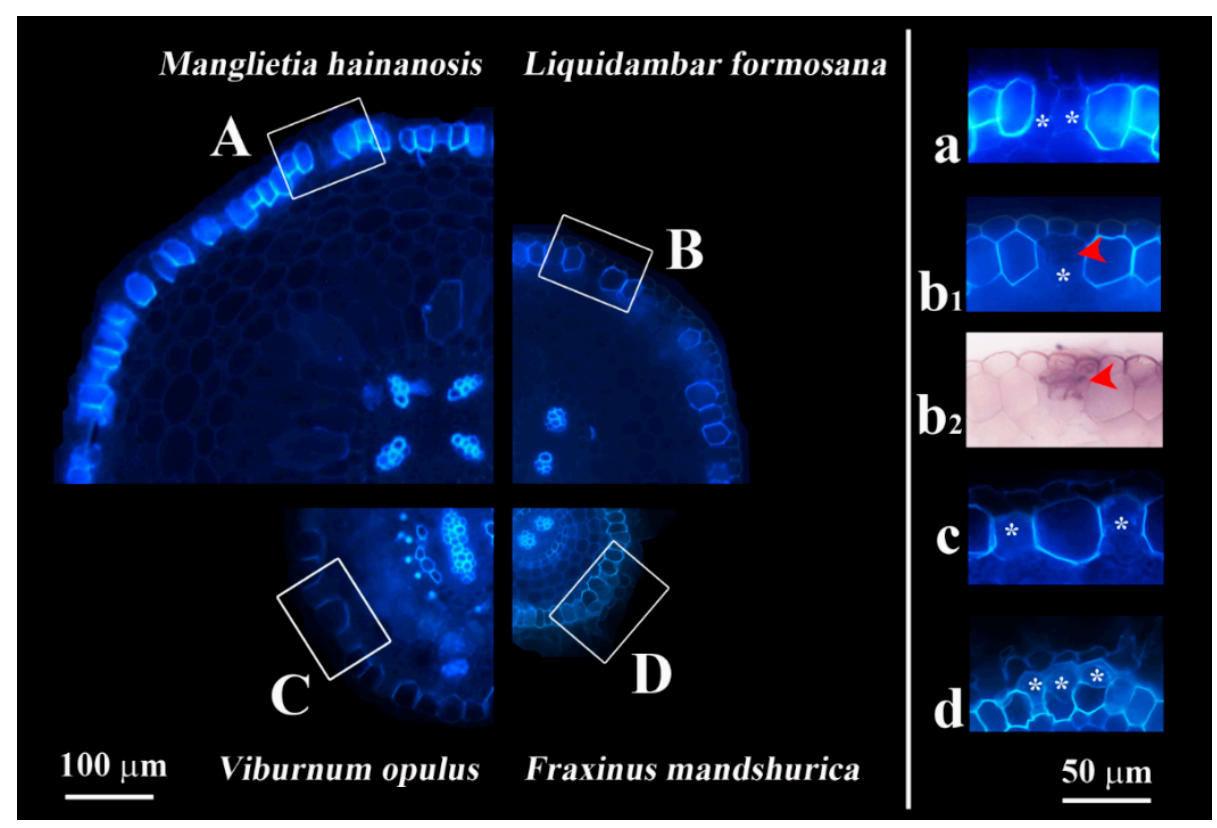

Figure 2. Typical passage cells (asterisk) in tropical $(\mathbf{A}, \mathbf{a}, \mathbf{B}, \mathbf{b})$ and temperate $(\mathbf{C}, \mathbf{c}, \mathbf{D}, \mathbf{d})$ species, respectively. Mycorrhizal hypha coiling (red arrow) within passage cell was observed under UV blue ( $\left.\mathbf{b}_{\mathbf{1}}\right)$ and white $\left(\mathbf{b}_{\mathbf{2}}\right)$ light in Liquidambar formosana, respectively.

All root cross-sections were observed by a BX-51 epifluorescence microscope (Olympus, Tokyo, Japan) equipped with a BH2-RFL-T3 high-intensity mercury light source (365 $\mathrm{nm})$, and only the ones with complete structures and distinct tissues and cells were selected for subsequent analyses. Both control and fluorescent root sections micrographs were taken for trait measurements. Here, we mainly chose blue and red filters on the microscope. Under UV light, PCs were distinguished based on their low fluorescence of cell walls caused by little suberin deposition [33] (Figure 2a-c in this study) or the special ingrowth in their outer tangential wall [12] (Figure 2d in this study). For each species, root cross-sections were photographed using a Motic 3000 CCD camera (Motic, Xiamen, China), then the number of hypodermis cells and passage cells were recorded, respectively. The proportion (\%) of passage cells (PCPs) in each root cross-section was calculated as the number of passage cells (PCNs) divided by the total number of hypodermis cells [34]. Specifically, the proportion of passage cells colonized by AM hypha (PCPM) was also calculated as the number of passage cells colonized by fungi (PCNM) divided by the total PCNs (Table 2). 
Table 2. Abbreviation and description of root morphological, anatomical, and mycorrhizal colonization traits in two forest types.

\begin{tabular}{|c|c|c|c|c|c|c|c|c|c|c|c|c|c|c|}
\hline \multicolumn{10}{|c|}{ Tropical Species } & \multicolumn{4}{|c|}{ Temperate Species } & \multirow[b]{2}{*}{$\begin{array}{l}p \text { Value for } \\
\text { the } t \text {-Test }\end{array}$} \\
\hline Functional Traits & Abbreviation & Units & Description & Mean & Med & Min & Max & CV (\%) & Mean & Med & Min & Max & CV (\%) & \\
\hline \multicolumn{15}{|c|}{ Mycorrhizal colonization } \\
\hline $\begin{array}{c}\text { Mycorrhizal } \\
\text { colonization rate }\end{array}$ & MCR & $\%$ & $\begin{array}{l}\text { Percentage of cortical cells } \\
\text { colonized by arbuscules, } \\
\text { vesicles or coil in all cortical } \\
\text { cells (including hypodermis, } \\
\text { cortical parenchyma cells } \\
\text { and endodermis) }\end{array}$ & 23.30 & 20.91 & 4.16 & 52.60 & 69.4 & 30.84 & 17.79 & 8.98 & 66.27 & 75.6 & 0.20 \\
\hline \multicolumn{15}{|c|}{ Anatomy } \\
\hline Cortex thickness & $\mathrm{CT}$ & $\mu \mathrm{m}$ & $\begin{array}{l}\text { Average thickness of cortex } \\
\text { including hypodermis, } \\
\text { cortical parenchyma cells } \\
\text { and endodermis }\end{array}$ & 185.32 & 163.04 & 67.40 & 466.36 & 60.5 & 106.94 & 85.24 & 59.19 & 217.33 & 49.7 & 0.024 \\
\hline $\begin{array}{l}\text { Number of } \\
\text { passage cells }\end{array}$ & PCN & & $\begin{array}{l}\text { Average number of passage } \\
\text { cells in the exodermis per } \\
\text { root cross-section }\end{array}$ & 15.56 & 13.11 & 5.20 & 37.61 & 47.3 & 9.94 & 7.45 & 6.13 & 17.88 & 47.9 & 0.055 \\
\hline $\begin{array}{l}\text { Proportion of } \\
\text { passage cells }\end{array}$ & PCP & $\%$ & $\begin{array}{l}\text { Average proportion of } \\
\text { passage cells in the } \\
\text { hypodermis per root } \\
\text { cross-section }\end{array}$ & 22.27 & 20.73 & 18.79 & 28.18 & 16.6 & 24.89 & 21.78 & 17.02 & 43.19 & 31.9 & 0.18 \\
\hline $\begin{array}{c}\text { Number of } \\
\text { passage cells } \\
\text { colonized by fungi }\end{array}$ & PCNM & & $\begin{array}{l}\text { Average number of hypha } \\
\text { phpenetration point through } \\
\text { passge cells }\end{array}$ & 2.94 & 2,39 & 1.70 & 7.28 & 55.2 & 3.55 & 1.41 & 0.73 & 13.60 & 119.7 & 0.41 \\
\hline $\begin{array}{l}\text { Proportion of } \\
\text { passage cell } \\
\text { colonized by } \\
\text { hypha }\end{array}$ & РCPM & $\%$ & $\begin{array}{l}\text { Average proportion point of } \\
\text { hypha through passage cells }\end{array}$ & 22.95 & 2.83 & 14.40 & 33.79 & 24.64 & 28.17 & 18.91 & 10.63 & 90.4 & 82.39 & 0.23 \\
\hline \multicolumn{15}{|c|}{ Morphology } \\
\hline Root diameter & $\mathrm{RD}$ & $\mu \mathrm{m}$ & $\begin{array}{l}\text { Average diameter of root } \\
\text { tips }\end{array}$ & 534.29 & 492.67 & 210.35 & 1313.10 & 43.3 & 316.71 & 260.57 & 193.73 & 566.75 & 44.5 & 0.022 \\
\hline
\end{tabular}

Note: Med, median; Min, minimum; Max, maximum; $\mathrm{CV}$, coefficient of variation. 
For each root transverse slice, root traits were measured to the nearest $1 \mu \mathrm{m}$ using the Motic Images Advanced 3.2 software. Root diameter $(\mu \mathrm{m})$, cortex thickness $(\mu \mathrm{m})$, and stele (i.e., vascular cylinder) diameter $(\mu \mathrm{m})$ of a transverse root section were measured in five crossing radial directions and averaged for each species.

\subsection{Root Arbuscular Mycorrhizal Colonization}

AM colonization was determined by carefully examining root anatomical structures, including hyphal coils, arbuscules, and vesicles. Obviously, the appearance of AM structures within cortical cells is the result of the longitudinal and transverse expansion of AM fungi $[2,35]$. In crop roots, arbuscules in root cross-sections could be observed using laser ablation tomography, and their number could be counted [36]. Therefore, it was convincing that the AM colonization rate (MCR) could be calculated using the proportion of cortical cells colonized by AM fungi in the root cross-section. Finally, the mean MCR for the species was determined by averaging the examined 17-31 root segments. In this study, all measured root traits were originally taken from the root cross-section, and all of them were in the same dimension.

\subsection{Data Analysis}

At each study site, mean and coefficient of variation $(\mathrm{CV})$ were calculated for the quantitative traits of PCs (i.e., PCN, PCP, PCNM, and PCPM), root morphology (i.e., root diameter), and anatomy (i.e., cortex) across tree species. For traits expressed as percentages (i.e., PCP, PCPM), the Bliss angular transformation was used before analyzing. As limited by the sample size of woody species, a $t$-test $(p=0.05)$ was used to compare the differences of the means of PCN, PCP, and other functional traits between tropical and temperate forests. Correlations between pairwise root traits across tropical, temperate, and all 22 selected species were determined separately using Pearson's correlation coefficient. The slopes and intercepts of correlations between two biomes were compared using an analysis of covariance (ANCOVA). All statistical analyses were performed by using SPSS 19.0 (IBM Corp., Armonk, NY, USA), and data visualizations were made using SigmaPlot 10.0 (Systat Software Inc., San Jose, CA, USA).

\section{Results}

\subsection{Variations of Passage Cells, Arbuscular Mycorrhizal Colonization, and Other Root} Functional Traits

Significant interspecific variations in root functional traits were found across tropical and temperate species (Figure 2, Figures S2 and S3, Table 2, Tables S2 and S3), respectively. Moreover, root functional traits showed large variations between tropical and temperate forests (Table 2, Figure 2). On average, compared with the temperate species, the tropical ones had significantly wider root diameter $(534.29 \mu \mathrm{m}$ vs. $316.71 \mu \mathrm{m})$, cortex thickness (185.32 $\mu \mathrm{m}$ vs. $106.94 \mu \mathrm{m})$, and marginally higher PCN (15.56 vs. 9.94, $p=0.055$, Table 2, Tables S2 and S3). However, their variation ranges (CVs) within each biome were quite similar. By contrast, the AM colonization rate (23.30\% vs. 30.84\%), PCP (22.27\% vs. 24.89\%), and both number (PCNM, 3.12 vs. 3.42) and proportion (PCPM, 22.95\% vs. $28.17 \%$ ) of PCs colonized by AM fungi were much similar $(p>0.05)$ between biomes, whereas their CVs were wider in the temperate forest than tropical forest (Table 2).

\subsection{Relationships of Passage Cells to Arbuscular Mycorrhizal Colonization and Other Root Functional Traits}

Root morphology, anatomy, and AM colonization were tightly coordinated. In both temperate and tropical forests, it was PCN, rather than PCP, that was significantly positively correlated with AM colonization rate (Figure $3 a, b)$. When all of the species were pooled across biomes, both PCN and PCP were positively correlated with AM colonization rate (Figure $3 a, b)$. For the PCs colonized by AM fungi, both their number (PCNM) and proportion (PCPM) were positively related to AM colonization rate across temperature or all species, but not for tropical ones (Figure $3 c, d$ ) 

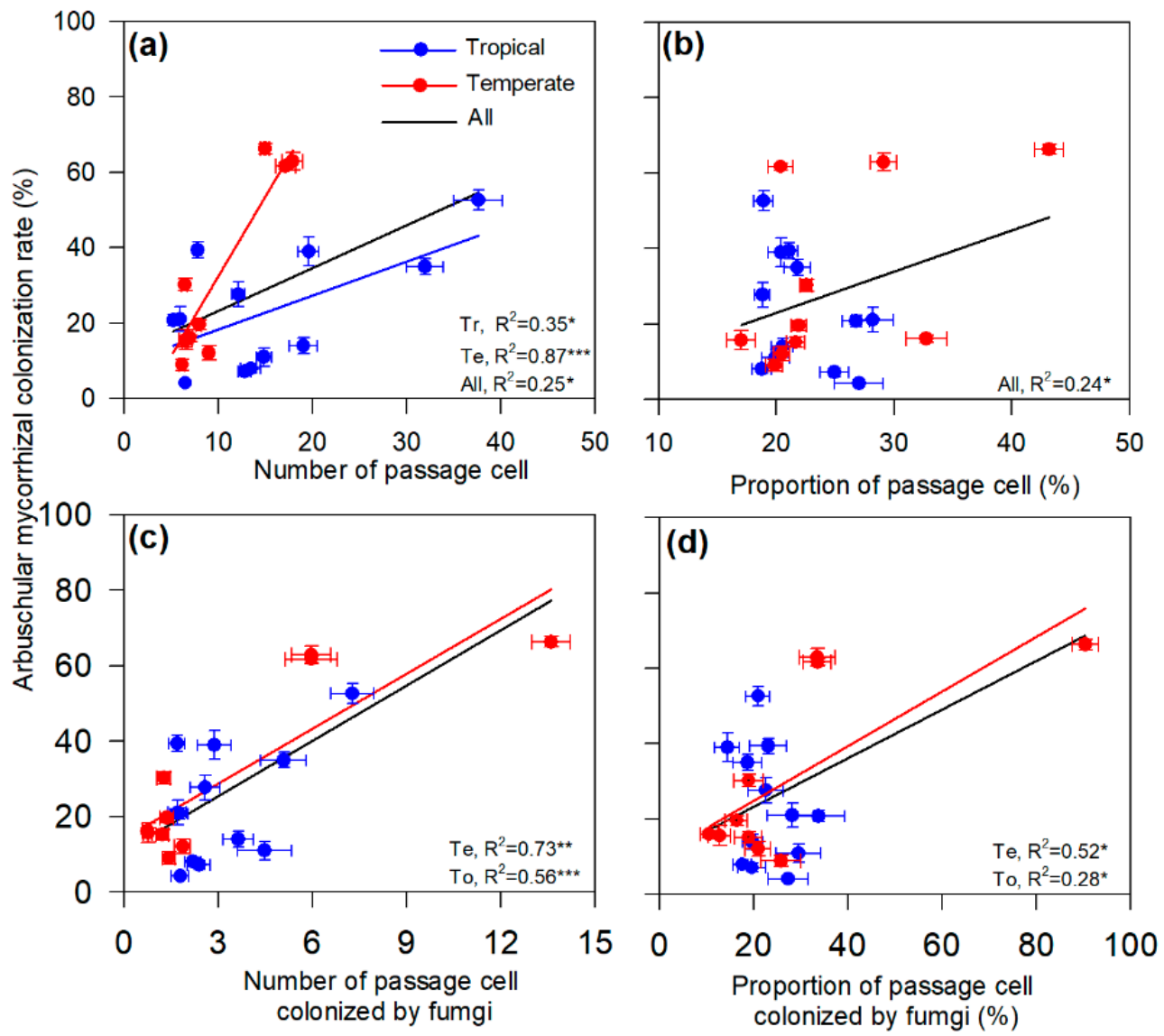

Figure 3. The relationships between mycorrhizal colonization rate and the total number (a) and proportion (b) of passage cells, and the number (c) and proportion (d) of passage cells colonized by arbuscular mycorrhizal fungi, respectively. Tr, Te, and All represent tropical, temperate, and total species, respectively. ${ }^{*} p<0.05,{ }^{* *} p<0.01,{ }^{* * *} p<0.001$.

Moreover, PCN was also positively related to root diameter (Figure 4a) and cortex thickness (Figure 4b), respectively, and the correlation coefficients were in similar tendency in both biomes (no significant difference were observed between the slopes, $p>0.05$, Table 3). On the contrary, PCP was relatively independent of root morphology and anatomy (Figure 4c,d). AM colonization rate increased linearly with root and cortex thickening (Figure 4e,f), with the slope for temperate species much steeper than the tropical one $(p<0.05$, Table 3$)$; these positive relationships still existed when all species were taken together. Briefly, more PCs in thick roots conferred by the wide cortex were strongly associated with a high AM colonization rate (Figure 3, Figure 4 and Figure S4).

Table 3. The results of ANCOVA of slope and intercept of the significantly positive linear regressions of root functional trait correlation depicted in Figures 3 and 4. MCR, mycorrhizal colonization rate; $\mathrm{PCN}$, the number of passage cells; RD, root diameter; $\mathrm{CT}$, cortex thickness.

\begin{tabular}{ccccccc}
\hline \multirow{2}{*}{ Trait Pair } & \multicolumn{3}{c}{ Slope } & & \multicolumn{3}{c}{ Intercept } \\
\cline { 2 - 7 } & MS & F & $p$-Value & MS & F & $p$-Value \\
\hline MCR-PCN & 71.177 & 1.667 & 0.213 & 301.623 & 6.824 & 0.017 \\
RD-MCR & 2004.054 & 14.238 & 0.001 & 1499.971 & 6.281 & 0.021 \\
RD-PCN & 0.764 & 0.071 & 0.793 & 4.966 & 0.485 & 0.494 \\
CT-MCR & 1700.018 & 11.101 & 0.004 & 1509.958 & 6.437 & 0.02 \\
CT-PCN & 0.115 & 0.014 & 0.908 & 5.477 & 0.69 & 0.416 \\
\hline
\end{tabular}



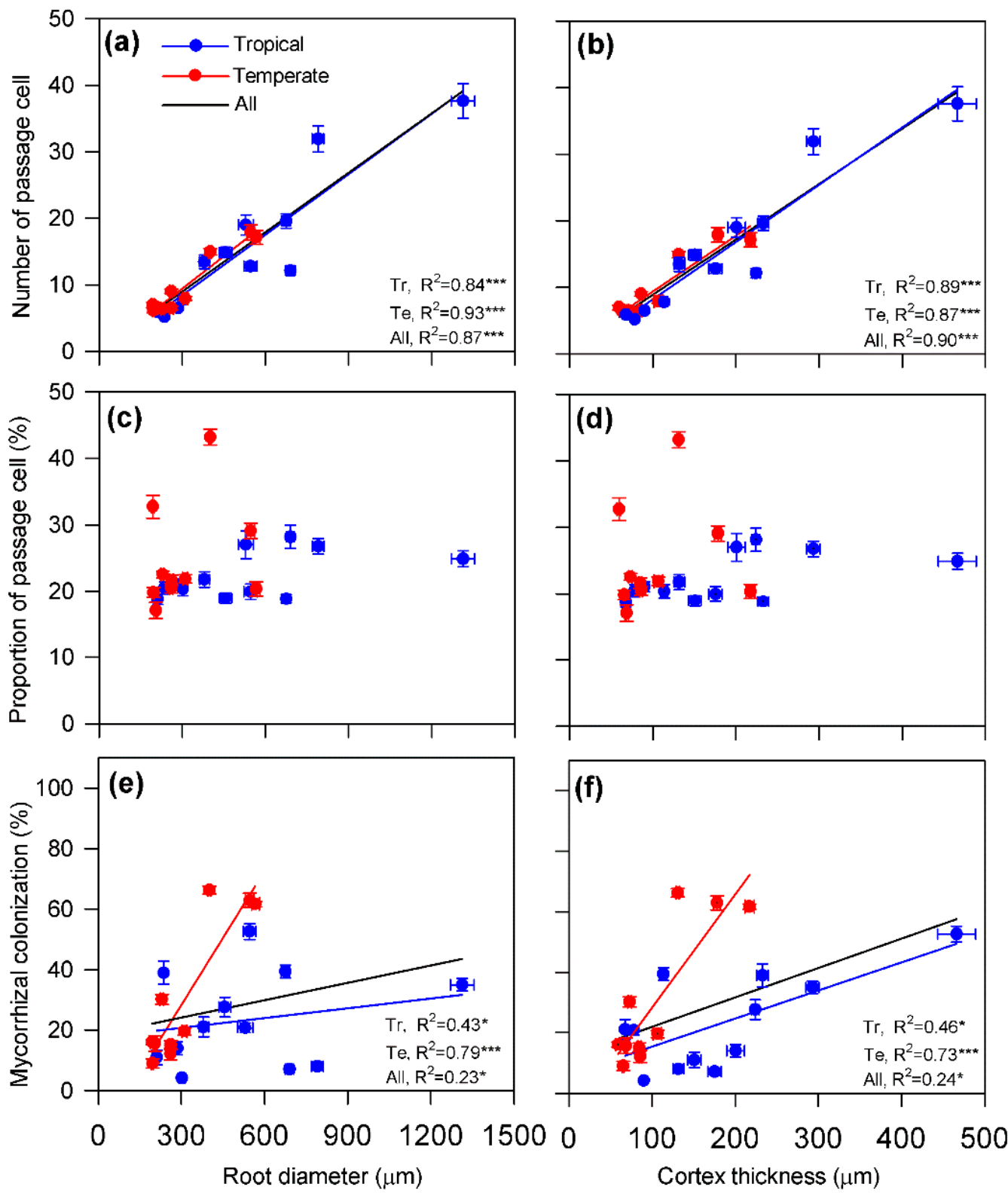

Figure 4. The relationships between the number and proportion of passage cells, mycorrhizal colonization rate, and root diameter $(\mathbf{a}, \mathbf{c}, \mathbf{e})$, and cortex thickness $(\mathbf{b}, \mathbf{d}, \mathbf{f})$. $\mathrm{Tr}, \mathrm{Te}$, and All represent tropical, temperate, and total species, respectively. ${ }^{*} p<0.05,{ }^{* *} p<0.01,{ }^{* * *} p<0.001$.

\section{Discussion}

In this study, we assessed the magnitude of quantitative variations of root hypodermis PCs in 22 woody species from two contrasting biomes and investigated their potential relationships with other root functional traits associated with resource acquisition. To the best of our knowledge, this is the first report to demonstrate that it is PCN, rather than $\mathrm{PCP}$, that is positively related to AM colonization rate, root diameter, and cortex thickness across species. These results highlight the coordination of PCs in the establishment of AM symbiont. Indeed, PCs, together with diameter and cortex, are crucial components of root resource acquisition. These findings also provide key information to understand the collaboration gradients of root economics space. 


\subsection{Tight Linkages between Passage Cells, and Root Morphology, Anatomy, and Arbuscular Mycorrhizal Colonization}

Inconsistent with previous results reported in Xu et al. [21], our results showed that it was PCN, rather than PCP, that positively correlated with AM colonization rate, root diameter, and cortex thickness; PCP was relatively independent of other traits.

Why do thick-root species with wider cortex contain more PCs? This may be associated with the different nutrient-foraging strategies adopted by thin- and thick-root species. Recently, some studies have shown that thin-root species forage nutrients mainly via fine roots, such as the proliferation of root length or mass, whereas thick-root species rely more on extremely fine-structured AM fungi in both temperate [10] and subtropical forests [4]. Notably, thick-root species generally have thick cortex $[23,27,37]$ and more PCs [22, this study], which also positively correlated with each other in this study (Figures 3 and 4). Therefore, for the structural specialization in thick roots with wider cortex and high arbuscular AM colonization [11], more PCs providing adequate AM-fungi-penetrating sites were also essential supplementary traits.

Additionally, in both biomes, root diameter would explain similar variation in PCN, which was also the same as cortex thickness, manifested by the nearly same slopes, indicating that these tight linkages between PCN and root diameter and cortex thickness were general trends across different biomes or forest types.

In our study, PCP was relatively independent of AM colonization rate, root diameter, and cortex thickness, but its underlying mechanism is not well understood. We speculate that the dual roles of hypodermis cells in physical and physiological parameters could account for the patterns. On the one hand, the physical and biochemical characteristics of PCs (mentioned above) could enable PCs to function as penetration points for arbuscular AM fungi $[17,20]$ and also serve as key regulators for ions absorbed through the symplasm pathway $[17,38,39]$. Conversely, more PCs would also provide more entry points for pathogen infection $[17,40,41]$ and increase the possibility of ion backflow [33]. On the other hand, a suberized wall of non-passage cells could protect roots from pathogen infection and prevent ion backflow. However, no doubt, these non-passage cells would also impede the entry of foreign substances, i.e., hypha and ion $[17,33]$. Consequently, there may be an inherent trade-off between resource absorption and pathogenic defense within hypodermis, resulting in the relatively independent $\mathrm{PCP}$ across different woody species, unrelated to root morphology, anatomy, and AM colonization.

Additionally, according to the dataset of PCs in five North American woody species [29], the PCP (calculated in the cross-section of fibrous roots, similarly to our study) ranged from $15 \%$ to $32 \%$, which was similar to our results. Therefore, absorptive roots could regulate $\mathrm{PCN}$ by maintaining a relatively stable $\mathrm{PCP}$, achieving an optimal balance between resource uptake and providing AM fungi penetrating points. Hence, more relevant information about PCP across different species is urgently needed for understanding the root resource acquisition and survival strategies.

\subsection{Variations of Root Traits between Temperate and Tropical Forests}

On average, the PCN of tropical species was $56 \%$ higher than that of temperate species. This pattern might be explained by the prevalent thick-root species in tropical forests. The relatively stable hot and humid climate in tropical zones could enable those ancestral phylogenetic groups that generally have thick roots such as Magnoliaceae (Manglietia hainanosis) and Lauraceae (Alseodaphne hainanensis) to survive to the present $[8,10,27,37,42]$. Therefore, more thick-root species remained in tropical forests, which was similar to other studies containing more species [8]. As PCN was positively correlated with root diameter in both tropical and temperate forests (Figure 3), tropical tree species with thicker root tips generally possess more PCs. Additionally, small-scale experiments proved that high soil moisture [43] and low nutrient availability (e.g., nitrogen or phosphorus) [31,44] would stimulate the PCs formation. Herein, in tropical forests, owing to high precipitation and leaching, moist but nutrient-poor soils might cause a greater PCN than temperate ones. 
Therefore, at the regional scale, altered species composition and soil conditions may be the main factors influencing PCN.

Furthermore, we also noted that CVs of PCP and PCPM were higher in temperate forests than tropical ones. This may be caused by Schisandra chinensis, as its PCP (43\%) and PCPM (90\%) were significantly greater than other temperate species. If this species was excluded, the CVs of PCP and PCPM in temperate forests would reduce to $21 \%$ and $29 \%$, respectively, close to those (15\% and $22 \%$ ) of tropical ones. Compared with other self-supporting trees and shrubs, $S$. chinensis is a liana and can climb up to a tall canopy, probably showing distinct ecological performance, including root resource competition and acquisition strategies $[45,46]$, which may result in a larger variation in PC characteristics in temperate species.

Additionally, both the number and proportion of PCs colonized by AM fungi were also found to be significantly positively correlated with AM colonization rate in temperate forests, and steeper linear regressions related to AM colonization were also obvious in temperate forests, e.g., the trait pairs within AM colonization rate and PCN, root diameter, and cortex thickness. There was a slightly higher AM colonization rate but marginally fewer PCs in temperate fine roots than tropical ones. Nevertheless, the underlying mechanism causing such patterns is not well understood, which might be related to the absorption of PCs. Previous studies proved that PCs lacked suberin lamella deposition and had greater permeability, consequently facilitating water and nutrients entry and movement across the root section [17,33]. For example, Storey and Walker [39] reported that exodermis PCs had relatively higher ion concentrations (e.g., $\mathrm{K}+$ ) than epidermal cells in citrus seedling roots. Therefore, compared with tropical species, fewer PCs in root cross-section, but a higher number and proportion of PCs colonized by AM fungi and higher mycorrhizal colonization rate would enhance the absorptive capacity of fine roots in temperate forests.

\section{Conclusions}

In both tropical and temperate forests, it was the number of passage cells, rather than the proportion, that positively related to mycorrhizal colonization rate, root diameter, and cortex thickness. In thick roots, more passage cells would provide more penetrate sites for mycorrhizal hyphae, and a wider cortex would offer adequate growth space, consequently increasing the mycorrhizal colonization rate and facilitating resource acquisition. The proportion of passage cells seems to be independent of other root traits, which may contribute to the balance between resource acquisition and pathogenic defense. These results highlight the crucial role of passage cells in mycorrhizal colonization and resource acquisition. Our findings also provide new empirical evidence to support the conceptual framework of root economics space in woody plants.

Supplementary Materials: The following supporting information can be downloaded at: https: / / www.mdpi.com/article/10.3390/f13020140/s1, Table S1: Geographical information and soil characteristics of tropical and temperate forests (mean \pm 1 standard error); Table S2: Root functional traits in 12 tropical species (mean \pm 1 standard error, $n=17-26$ ); Table S3: Root functional traits in 10 temperature species (mean \pm 1 standard error, $n=26-31$ ); Figure S1: Cross-section of the ectomycorrhizal root of Betula platyphylla; Figure S2: Anatomical structures of the root tips of 12 Chinese tropical woody species. A, a: Acronychia pedunculata; B, b: Alangium chinense; C, c: Alseodaphne hainanensis; D, d: Aporosa dioica; E, e: Aquilaria sinensis; F, f: Cratoxylum cochinchinense; G, g: Eucommia ulmoides; H, h: Fortunella margrita; I, i: Liquidambar formosana; J, j: Manglietia hainanosis; K; k: Sterculia lanceolata; L, 1: Viburnum odoratissimum. EP, epidermis; EX, exodermis; CO, cortex; VC, vascular cylinder (stele); EN, endodermis. Asterisk indicates the passage cell; Figure S3: Anatomical structures of the root tips of 10 Chinese temperate woody species. A, a: Acer mandshuricum; B, b: Acer ginnala; C, c: Acer mono; D, d: Euonymus alatus; E, e: Fraxinus mandshurica; F, f: Lonicera maackii; G, g: Phellodendron amurense; H, h: Schisandra chinensis; I, i: Syringa amurensis; J, j: Viburnum calvescens. EP, epidermis; EX, exodermis; CO, cortex; EN, endodermis; VC, vascular cylinder (stele); Asterisk indicates the passage cell; Figure S4: 
The relationship between root diameter and cortex thickness (a) and stele diameter (b). Tr, Te, and All represent tropical, temperate, and total species, respectively. ${ }^{*} p<0.05,{ }^{* *} p<0.01,{ }^{* *} p<0.001$.

Author Contributions: Conceptualization, J.G.; funding acquisition, Y.W. and J.G.; investigation, Y.W., Z.L. and N.W.; methodology, Y.W., Z.L., S.W., W.W. and N.W.; software, Y.W., W.W. and N.W.; supervision, J.G.; visualization, S.W. and W.W.; writing-original draft preparation, Y.W., Z.L. and J.G.; writing-review and editing, Y.W. and J.G. All authors have read and agreed to the published version of the manuscript.

Funding: This research was jointly supported by the National Natural Science Foundation of China (32101514, 31870608, and 31100470) and Fundamental Research Funds for the Central Universities (2572018BA11).

Data Availability Statement: The data presented in this study are available on request from the corresponding author. The data are not publicly available due to privacy restrictions.

Acknowledgments: We thank Zhengquan Wang, Lei Cui, Xueyun Dong, and Hongfeng Wang for their assistance with laboratory work. We also thank Timothy J. Fahey, Lisa A. Donovan, and Donovan's Lab colleagues for comments that improved an earlier draft of this article.

Conflicts of Interest: The authors declare no conflict of interest.

\section{References}

1. Genre, A.; Lanfranco, L.; Perotto, S.; Bonfante, P. Unique and common traits in mycorrhizal symbioses. Nat. Rev. Microbiol. 2020, 18, 649-660. [CrossRef]

2. Brundrett, M.C.; Tedersoo, L. Resolving the mycorrhizal status of important northern hemisphere trees. Plant Soil 2020, 454, 3-34. [CrossRef]

3. Liu, B.; Li, H.; Zhu, B.; Koide, R.T.; Eissenstat, D.M.; Guo, D. Complementarity in nutrient foraging strategies of absorptive fine roots and arbuscular mycorrhizal fungi across 14 coexisting subtropical tree species. New Phytol. 2015, 208, 125-136. [CrossRef]

4. Ven, A.; Verlinden, M.S.; Verbruggen, E.; Vicca, S. Experimental evidence that phosphorus fertilization and arbuscular mycorrhizal symbiosis can reduce the carbon cost of phosphorus uptake. Funct. Ecol. 2019, 33, 2215-2225. [CrossRef]

5. Brundrett, M.C.; Tedersoo, L. Evolutionary history of mycorrhizal symbioses and global host plant diversity. New Phytol. 2018, 220, 1108-1115. [CrossRef]

6. Brundrett, M.C. Coevolution of roots and mycorrhizas of land plants. New Phytol. 2002, 154, 275-304. [CrossRef]

7. Li, H.; Liu, B.; McCormack, M.L.; Ma, Z.; Guo, D. Diverse belowground resource strategies underlie plant species coexistence and spatial distribution in three grasslands along a precipitation gradient. New Phytol. 2017, 216, 1140-1150. [CrossRef] [PubMed]

8. Ma, Z.; Guo, D.; Xu, X.; Lu, M.; Bardgett, R.D.; Eissenstat, D.M.; McCormack, M.L.; Hedin, L.O. Evolutionary history resolves global organization of root functional traits. Nature 2018, 555, 94-97. [CrossRef]

9. Cheng, L.; Chen, W.; Adams, T.; Wei, X.; Li, L.; McCormack, M.L.; Deforest, J.L.; Koide, R.; Eissenstat, D.M. Mycorrhizal fungi and roots are complementary in foraging within nutrient patches. Ecology 2016, 97, 2815-2823. [CrossRef]

10. Chen, W.; Koide, R.T.; Adams, T.S.; DeForest, J.L.; Cheng, L.; Eissenstat, D.M. Root morphology and mycorrhizal symbioses together shape nutrient foraging strategies of temperate trees. Proc. Natl. Acad. Sci. USA 2016, 113, 8741-8746. [CrossRef] [PubMed]

11. Bergmann, J.; Weigelt, A.; van der Plas, F.; Laughlin, D.C.; Kuyper, T.W.; Guerrero-Ramírez, N.; Valverde-Barrantes, O.J.; Bruelheide, H.; Freschet, G.T.; Iversen, C.M.; et al. The fungal collaboration gradient dominates the root economics space in plants. Sci. Adv. 2020, 6, aabs3756. [CrossRef]

12. Wilson, A.J.; Robards, A.W. Observations of the pattern of secondary wall development in the hypodermis of onion (Allium cepa) roots. Protoplasma 1980, 104, 149-156. [CrossRef]

13. Kretzschmar, T.; Kohlen, W.; Sasse, J.; Borghi, L.; Schlegel, M.; Bachelier, J.B.; Reinhardt, D.; Bours, R.; Bouwmeester, H.J.; Martinoia, E. A petunia ABC protein controls strigolactone-dependent symbiotic signalling and branching. Nature 2012, 483, 341-344. [CrossRef] [PubMed]

14. Waldie, T.; McCulloch, H.; Leyser, O. Strigolactones and the control of plant development: Lessons from shoot branching. Plant J. 2014, 79, 607-622. [CrossRef] [PubMed]

15. Banasiak, J.; Borghi, L.; Stec, N.; Martinoia, E.; Jasiński, M. The full-size ABCG transporter of Medicago truncatula is involved in strigolactone secretion, affecting arbuscular mycorrhiza. Front. Plant. Sci. 2020, 11, 18. [CrossRef] [PubMed]

16. Aquino, B.; Bradley, J.M.; Lumba, S. On the outside looking in: Roles of endogenous and exogenous strigolactones. Plant J. 2021, 105, 322-334. [CrossRef]

17. Peterson, C.A.; Enstone, D.E. Functions of passage cells in the endodermis and exodermis of roots. Physiol. Plant. 1996, 97, 592-598. [CrossRef] 
18. Ejiri, M.; Shiono, K. Groups of multi-cellular passage cells in the root exodermis of Echinochloa crus-galli varieties lack not only suberin lamellae but also lignin deposits. Plant Signal. Behav. 2020, 15, e1719749. [CrossRef]

19. Liu, G.; Stirnemann, M.; Gübeli, C.; Egloff, S.; Courty, P.-E.; Aubry, S.; Vandenbussche, M.; Morel, P.; Reinhardt, D.; Martinoia, E.; et al. Strigolactones play an important role in shaping exodermal morphology via a KAI2-dependent pathway. iScience 2019, 17, 144-154. [CrossRef] [PubMed]

20. Sharda, J.N.; Koide, R.T. Can hypodermal passage cell distribution limit root penetration by mycorrhizal fungi? New Phytol. 2008, 180, 696-701. [CrossRef]

21. Xu, L.; Wang, S.; Liu, Y.; Ji, L.; Shen, F.; Yang, L. Responses of mycorrhizal colonization to nitrogen and phosphorus addition in fourteen woody and herbaceous species: The roles of hypodermal passage cells and penetration points. Plant Soil 2021, 469, 273-285. [CrossRef]

22. Eissenstat, D.M.; Achor, D.S. Anatomical characteristics of roots of citrus rootstocks that vary in specific root length. New Phytol. 1999, 141, 309-321. [CrossRef] [PubMed]

23. Guo, D.; Xia, M.; Wei, X.; Chang, W.; Liu, Y.; Wang, Z. Anatomical traits associated with absorption and mycorrhizal colonization are linked to root branch order in twenty-three Chinese temperate tree species. New Phytol. 2008, 180, 673-683. [CrossRef]

24. Kong, D.; Wang, J.; Wu, H.; Valverde-Barrantes, O.J.; Wang, R.; Zeng, H.; Kardol, P.; Zhang, H.; Feng, Y. Nonlinearity of root trait relationships and the root economics spectrum. Nat. Commun. 2019, 10, 2203. [CrossRef] [PubMed]

25. de la Riva, E.G.; Prieto, I.; Marañón, T.; Pérez-Ramos, I.M.; Olmo, M.; Villar, R. Root economics spectrum and construction costs in Mediterranean woody plants: The role of symbiotic associations and the environment. J. Ecol. 2021, 109, 1873-1885. [CrossRef]

26. Guo, H.; Ayalew, H.; Seethepalli, A.; Dhakal, K.; Griffiths, M.; Ma, X.-F.; York, L.M. Functional phenomics and genetics of the root economics space in winter wheat using high-throughput phenotyping of respiration and architecture. New Phytol. 2021, 232, 98-112. [CrossRef]

27. Gu, J.; Xu, Y.; Dong, X.; Wang, H.; Wang, Z. Root diameter variations explained by anatomy and phylogeny of 50 tropical and temperate tree species. Tree Physiol. 2014, 34, 415-425. [CrossRef]

28. Gong, Z.T.; Chen, Z.C.; Luo, G.B. Soil reference with Chinese soil taxonomy. Soils 1999, 31, 57-63. (In Chinese)

29. Zadworny, M.; Eissenstat, D.M. Contrasting the morphology, anatomy and fungal colonization of new pioneer and fibrous roots. New Phytol. 2011, 190, 213-221. [CrossRef]

30. Brundrett, M.C.; Enstone, D.E.; Peterson, C.A. A berberine-aniline blue fluorescent staining procedure for suberin, lignin, and callose in plant tissue. Protoplasma 1988, 79, 133-142. [CrossRef]

31. Hishi, T.; Tateno, R.; Takeda, H. Anatomical characteristics of individual roots within the fine-root architecture of Chamaecyparis obtusa (sieb. \& zucc.) in organic and mineral soil layers. Ecol. Res. 2006, 21, 754-758.

32. Lux, A.; Morita, S.; Abe, J.; Ito, K. An improved method for clearing and staining free-hand sections and whole-mount samples Ann. Bot. 2005, 96, 989-996. [CrossRef]

33. Enstone, D.E.; Peterson, C.A.; Ma, F. Root endodermis and exodermis: Structure, function, and responses to the environment. J. Plant Growth Regul. 2003, 21, 335-351. [CrossRef]

34. Freschet, G.T.; Pagès, L.; Iversen, C.M.; Comas, L.H.; Rewald, B.; Roumet, C.; Klimešová, J.; Zadworny, M.; Poorter, H.; Postma, J.A.; et al. A starting guide to root ecology: Strengthening ecological concepts and standardizing root classification, sampling, processing and trait measurements. New Phytol. 2021, 232, 973-1122. [CrossRef]

35. Brundrett, M. Diversity and classification of mycorrhizal associations. Biol. Rev. 2004, 79, 473-495. [CrossRef]

36. Galindo-Castañeda, T.; Brown, K.M.; Kuldau, G.A.; Roth, G.W.; Wenner, N.G.; Ray, S.; Schneider, H.; Lynch, J.P. Root cortical anatomy is associated with differential pathogenic and symbiotic fungal colonization in maize. Plant Cell Environ. 2019, 42, 2999-3014. [CrossRef]

37. Kong, D.; Ma, C.; Zhang, Q.; Li, L.; Chen, X.; Zeng, H.; Guo, D. Leading dimensions in absorptive root trait variation across 96 subtropical forest species. New Phytol. 2014, 203, 863-872. [CrossRef] [PubMed]

38. Walker, R.R.; Sedgley, M.; Blesing, M.A.; Douglas, T.J. Anatomy, ultrastructure and assimilate concentrations of roots of citrus genotypes differing in ability for salt exclusion. J. Exp. Bot. 1984, 35, 1481-1494. [CrossRef]

39. Storey, R.; Walker, R.R. Some effects of root anatomy on $\mathrm{K}, \mathrm{Na}$ and $\mathrm{Cl}$ loading of citrus roots and leaves. J. Exp. Bot. 1987, 38, 1769-1780. [CrossRef]

40. Kamula, S.A.; Peterson, C.A.; Mayfield, C.I. Impact of the exodermis on infection of roots by Fusarium culmorum. Plant Soil 1994, 167, 121-126. [CrossRef]

41. Koyyappurath, S.; Conéjéro, G.; Dijoux, J.B.; Lapeyre-Montès, F.; Jade, K.; Chiroleu, F.; Gatineau, F.; Verdeil, J.L.; Besse, P.; Grisoni, M. Differential responses of Vanilla accessions to root rot and colonization by Fusarium oxysporum f. sp. radicis-vanillae. Front. Plant. Sci. 2015, 6, 1125. [CrossRef] [PubMed]

42. Comas, L.H.; Callahan, H.S.; Midford, P.E. Patterns in root traits of woody species hosting arbuscular and ectomycorrhizas: Implications for the evolution of belowground strategies. Ecol. Evol. 2014, 4, 2979-2990. [CrossRef] [PubMed]

43. North, G.B.; Nobel, P.S. Changes in hydraulic conductivity and anatomy caused by drying and rewetting roots of Agave deserti (Agavaceae). Am. J. Bot. 1991, 78, 906-915. [CrossRef]

44. Sharda, J.N.; Koide, R.T. Exploring the role of root anatomy in P-mediated control of colonization by arbuscular mycorrhizal fungi. Botany 2010, 88, 165-173. [CrossRef] 
45. Bastos, C.L.; Tamaio, N.; Angyalossy, V. Unravelling roots of lianas: A case study in Sapindaceae. Ann. Bot. 2016, 118, 733-746. [CrossRef]

46. Collins, C.G.; Wright, S.J.; Wurzburger, N. Root and leaf traits reflect distinct resource acquisition strategies in tropical lianas and trees. Oecologia 2016, 180, 1037-1047. [CrossRef] 